\title{
Application of Anodic Oxidation with Graphite Electrodes in Pretreated Leachates
}

\author{
T. J. Sánchez-Sánchez ${ }^{1}$ H. A. Nájera-Aguilar1', R. F. Gutiérrez-Hernández², C. M. García-Lara1, \\ J. A. Araiza-Aguilar1, J. A. Bautista-Ramírez³ , J. H. Castañón-González ${ }^{4}$ \\ ${ }^{1}$ Universidad de Ciencias y Artes de Chiapas, Tuxtla Gutiérrez, México \\ ${ }^{2}$ Departmento de Ingeniería Química y Bioquímica, Tecnológico Nacional de México/IT de Tapachula, Tapachula, México \\ ${ }^{3}$ Universidades para el Bienestar Benito Juárez García, Villa de Allende, Estado de México, México \\ ${ }^{4}$ Department of Chemical and Biochemical Engineering, Tecnológico Nacional de México/IT de Tuxtla Gutiérrez, \\ Tuxtla Gutiérrez, Mexico \\ Email: ^hugo.najera@unicach.mx
}

How to cite this paper: Sánchez-Sánchez, T.J. Nájera-Aguilar, H.A., Gutiérrez-Hernández, R.F., García-Lara, C.M., Araiza-Aguilar, J.A., Bautista-Ramírez, J.A. and CastañónGonzález, J.H. (2020) Application of Anodic Oxidation with Graphite Electrodes in Pretreated Leachates. Open Journal of Applied Sciences, 10, 69-77.

https://doi.org/10.4236/ojapps.2020.103006

Received: January 30, 2020

Accepted: March 8, 2020

Published: March 11, 2020

Copyright () 2020 by author(s) and Scientific Research Publishing Inc. This work is licensed under the Creative Commons Attribution International License (CC BY 4.0).

http://creativecommons.org/licenses/by/4.0/

\begin{abstract}
Currently, landfills are the main method used for the final disposal of urban solid waste. The degradation processes that waste goes through in these sites, alongside rainwater that percolates through them, generate highly polluting liquids (leachate). In the treatment of leachate, advanced oxidation processes (AOP) can significantly reduce the concentrations of different pollutants. Due to the high documented potential around AOPs, in this study, the effectiveness of anodic oxidation in the removal of the remaining organic load in leachates pretreated in a biological system was evaluated. Graphite electrodes were used as anode and cathode. The efficiency of anodic oxidation, in terms of the removal of chemical oxygen demand (COD) and color, was evaluated under different current densities $\left(7,12,17\right.$ and $\left.22 \mathrm{~mA} / \mathrm{cm}^{2}\right)$ and $\mathrm{pH}$ values $(3$, 4.5 and 6). Under the best conditions found $\left(22 \mathrm{~mA} / \mathrm{cm}^{2}\right.$ and $\mathrm{pH}$ of 6$)$ and with an oxidation time of 5 hours, a maximum removal of $68 \%$ in COD and $91 \%$ in color was achieved, which represented a quality in the final effluent of $271 \mathrm{mg} / \mathrm{L}$ and $151 \mathrm{Pt}-\mathrm{Co}$ in COD and color, respectively. Therefore, considering that graphite is an economic and widely available material, the results obtained show anodic oxidation, with the use of graphite electrodes, as a technically viable alternative as a final purification stage for pretreated leachates.
\end{abstract}

\section{Keywords}

Anodic Oxidation, Graphite Electrodes, Advanced Oxidation Processes

\section{Introduction}

Due to its economic advantages, landfills are one of the most used methods for 
the final disposal of urban solid waste in both developed and developing countries [1] [2].

Within landfills, leachate is generated as a result of the decomposition of organic matter and rainwater percolation [3]. Landfill leachates are complex effluents that contain all kinds of contaminants; many of them in high concentrations, so they are extremely difficult to treat [4] [5]. The composition and concentration of pollutants are influenced by the type of waste and the age of leachate [6]. Because of this, the method to be used for the treatment of these liquids depends on their composition and properties, as is the case with biodegradability. For leachates, this property is defined through the known Biodegradability Index (BI), which derives from the $\mathrm{BOD}_{5} / \mathrm{COD}$ ratio [7]. In general, when IB values are greater than 0.3 , the leachate is classified as young or biodegradable, and when the IB is less than 0.3 , the leachate is not biodegradable and is known as mature or old.

Young leachates with a high $\mathrm{BOD}_{5} / \mathrm{COD}$ ratio are effectively treated with biological methods [8]; these methods are the most efficient and low cost processes to eliminate most of the biodegradable organic matter present in leachate, such as volatile fatty acids. However, biological treatment is hampered by specific toxic substances (Polycyclic Aromatic Hydrocarbons, Absorbable Organic Halogens, Polychlorinated Biphenyls) and/or by the presence of biorecalcitrant organic compounds (humic substances or surfactants) [9]. For aqueous mediums of difficult degradation, physicochemical processes (coagulation-flocculation, chemical oxidation, membrane processes and adsorption with activated carbon, among others) have been used, either individually or in conjunction with biological processes; additionally, in recent years, other treatment alternatives such as the so-called AOPs have been tested, which are capable of degrading a large amount of organic pollutants into innocuous products, and where most of the AOPs are based on the production of the hydroxyl radical $(\bullet \mathrm{OH})$, which has a redox potential of $2.8 \mathrm{~V}$, making it the second most reactive species that exists in nature. In these processes, $\bullet \mathrm{OH}$ radicals initiate a series of oxidation reactions that lead to the final mineralization products, $\mathrm{CO}_{2}$ and $\mathrm{H}_{2} \mathrm{O}$ [10]. The advantage of the AOP's over every other chemical and biological process is that they are completely "environmentally friendly", since there is no transfer of pollutants from one phase to the other (as in chemical precipitation and adsorption) nor production of large amounts of dangerous sludge. AOPs are often applied together with other processes, whether biological or physicochemical, since if they are used as the sole treatment, it could be expensive [11]. A significant decrease in the total cost of leachates treatment could be obtained by combining AOP with a biological process [9]. Systems composed of a physicochemical or biological pretreatment coupled with an AOP have proven to be efficient, within the latter, anodic oxidation reports high removal efficiency in organic load of mature leachate from landfills, as reported by Anglada, et al. [12] and Fernandes [13]. In relation to the above, the objective of the present work was to evaluate the effectiveness of anodic 
oxidation as a final stage for the removal of organic contaminants from biologically pretreated leachate. The percentage of COD removal and color were the response variables.

\section{Materials and Methods}

\subsection{Characterization of Pretreated Leachate}

The influent used in this work came from a biological process and was characterized with the following parameters: COD, Biochemical Oxygen Demand (BOD), color, alkalinity, electrical conductivity and $\mathrm{pH}$. The COD was quantified using a closed reflux micrometer, digesting the sample at $150^{\circ} \mathrm{C}$ for $2 \mathrm{~h}$, and subsequently read on a HACH DR-5000 spectrophotometer at $620 \mathrm{~nm}$; in the case of BOD, the test was carried out by quantifying the difference between the initial dissolved oxygen concentration and the concentration after five days of incubation at $20^{\circ} \mathrm{C} \pm 1{ }^{\circ} \mathrm{C}$. Regarding color determination, a HACH DR/890 colorimeter was used and for the alkalinity the volumetric method was used, titrating with $0.02 \mathrm{~N}$ sulfuric acid, whereas electrical conductivity was measured with an EXTECH EC-150 conductivity meter. All analysis were developed following standardized methods [14] adapted to the particularities of the leachate.

\subsection{Experimental Trials}

The electrodegradation tests were conducted in an undivided electrolytic cell operated in a discontinuous regime (Figure 1), the system was maintained throughout the reaction time, with continuous stirring equal to $300 \mathrm{rpm}$. The electric current was applied by means of an EXTECH Instruments model 382270 power supply. During this study, graphite electrodes were used as cathode and anode, with a submerged area of $6 \mathrm{~cm}^{2}$; both were arranged vertically and parallel to each other (with a $2 \mathrm{~cm}$ gap) in the electrolytic reactor with $150 \mathrm{ml}$ of the leaching sample. For $\mathrm{pH}$ adjustment, $10 \% \mathrm{H}_{2} \mathrm{SO}_{4}$ was used.

\subsection{Experimental Design and Analysis of Experimental Data}

Experimental tests were carried out under a $3 \times 4$ factorial design, with $\mathrm{pH}$ and current density $(j)$ as factors and the following levels for each factor: $\mathrm{pH}(3,4.5$ and 6) and $j\left(7,12,17\right.$ and $\left.22 \mathrm{~mA} / \mathrm{cm}^{2}\right)$, with a total of 12 treatments (Table 1$)$. The percentage of COD removal and Color, determined according to Equation (1), were used as a response variable. The statistical analysis of the results obtained was carried out with the aid of an analysis of variance (ANOVA) with a level of significance $\alpha=0.05$ and with the help of the statistical package STATgraphics Centurion (version XVI.II). Prior to the analysis, the ANOVA assumptions were verified.

$$
\% \text { Removal }=\left(\frac{C_{i}-C_{f}}{C_{i}}\right) \times 100
$$

where: 


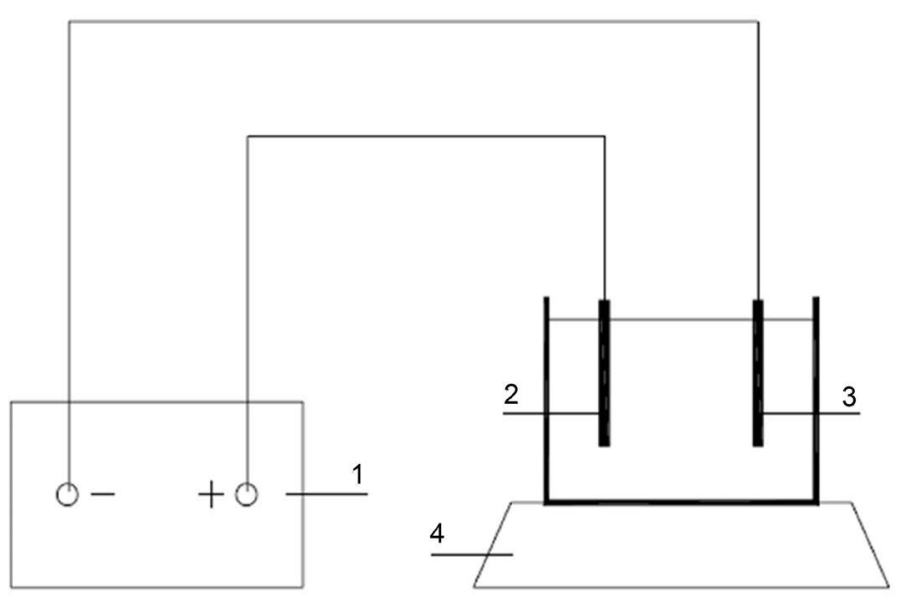

Figure 1. Experimental arrangement during the anodic oxidation process. Where: 1. Power source, 2. Anode, 3. Cathode, 4. Magnetic stirrer.

Table 1. Experimental design used in the anodic oxidation process.

\begin{tabular}{cccccc}
\hline & \multicolumn{5}{c}{$J\left(\mathrm{~mA} / \mathrm{cm}^{2}\right)$} \\
\hline & & $\mathbf{7}$ & $\mathbf{1 2}$ & $\mathbf{1 7}$ & $\mathbf{2 2}$ \\
$\mathrm{pH}$ & 3 & $\mathrm{~T} 1$ & $\mathrm{~T} 2$ & $\mathrm{~T} 3$ & $\mathrm{~T} 4$ \\
& 4.5 & $\mathrm{~T} 5$ & $\mathrm{~T} 6$ & $\mathrm{~T} 7$ & $\mathrm{~T} 8$ \\
& 6 & $\mathrm{~T} 9$ & $\mathrm{~T} 10$ & $\mathrm{~T} 11$ & $\mathrm{~T} 12$ \\
\hline
\end{tabular}

j: current density; T: Treatment.

$C_{i}=$ Initial concentration;

$C_{f}=$ Final concentration.

\section{Results and Discussion}

In the treatability tests carried out by anodic oxidation, leachates previously treated by a biological process were used, the characterization of this liquid used as influent to the electrochemical process is presented in Table 2.

These results show a liquid with a low biodegradability index $(\mathrm{BI}=0.07)$, which according to Foo and Hameed [15] is a mature leachate with recalcitrant characteristics, where electrochemical processes become a good treatment option [16] [17]. Likewise, it is observed that the organic load remaining from the pretreated leachate is still high, with COD values of $959 \mathrm{mg} / \mathrm{L}$ and $1685 \mathrm{Pt}-\mathrm{Co}$ in Color.

Another important parameter was the high value of electrical conductivity $(7.52 \mathrm{mS} / \mathrm{cm})$ that can be attributed to the high concentrations of chlorides present in the leachate, which favors electrochemical oxidation processes without the need to use additional electrolytes [12].

\section{COD and Color Removal}

The results obtained in the treatability tests by anodic oxidation are presented in Figure 2. As can be seen in this Fig, under the evaluated conditions, there is a 
Table 2. Characteristics of pretreated leachate.

\begin{tabular}{ccc}
\hline Parameter & Units & Value \\
\hline $\mathrm{BOD}_{5}$ & $\mathrm{mg} / \mathrm{L}$ & 72 \\
$\mathrm{COD}$ & $\mathrm{mg} / \mathrm{L}$ & 959 \\
$\mathrm{BI}^{*}$ & - & 0.075 \\
Color & $\mathrm{Pt}-\mathrm{Co}$ & 1685 \\
Electrical conductivity & $\mathrm{mS} / \mathrm{cm}$ & 7.52 \\
$\mathrm{pH}$ & - & 8.1 \\
\hline
\end{tabular}

*BI: Biodegradability index.

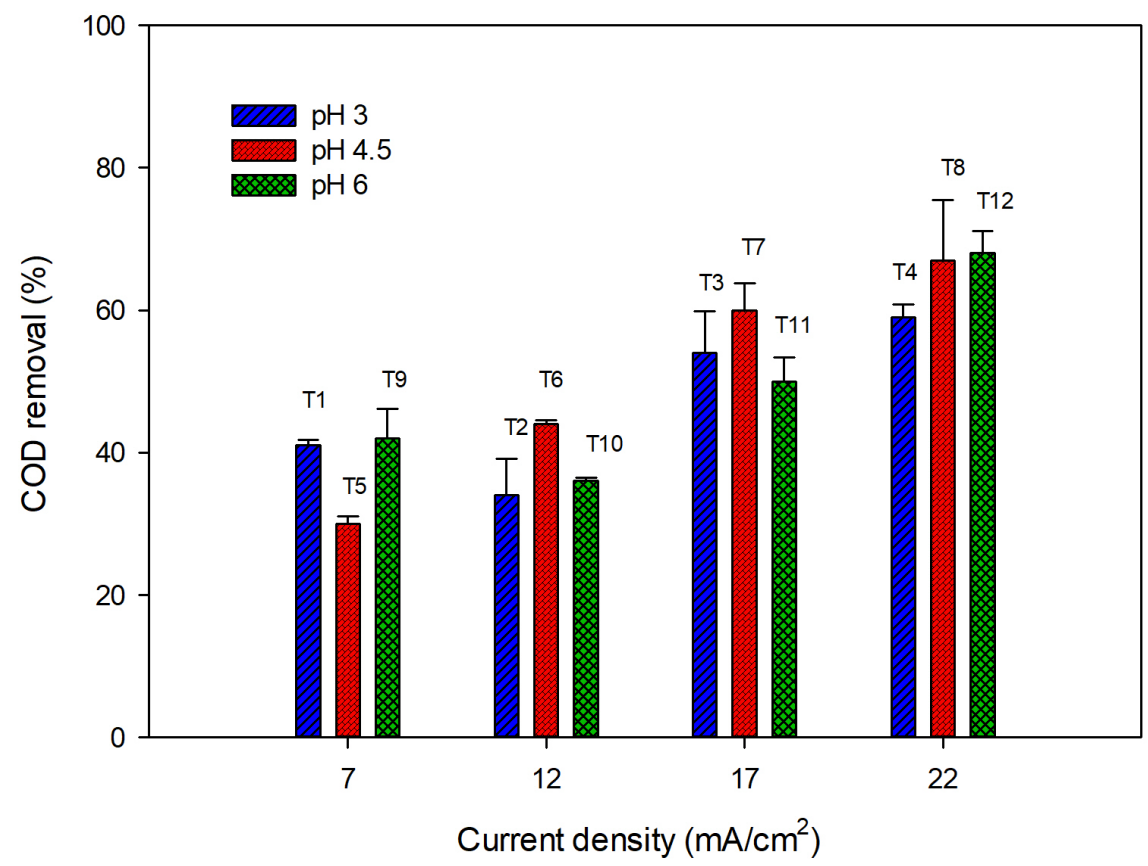

Figure 2. COD removal efficiencies at 5 hours of reaction.

direct relationship between COD removal and the $j$ supplied to the system, that is, the greater $j$, the greater COD removal. On the other hand, in the same Fig, it can be seen that the $\mathrm{pH}$ in the reaction medium showed interaction with $j$, that is, the effect of the $\mathrm{pH}$ corresponded to the $j$ supplied to the system.

On the other hand, the analysis of variance performed on the data obtained, allows us to see that the difference between the removal percentages achieved by the evaluated treatments is significant. The $\mathrm{T} 8$ and $\mathrm{T} 12$ treatments were the ones that obtained the highest percentage of removal, however, the difference between these two removal percentages was not significant, therefore, the T12 treatment was taken $\left(j=22 \mathrm{~mA} / \mathrm{cm}^{2}, \mathrm{pH}=6\right)$ as the best due to the fact that it operated under conditions closer to neutrality, unlike the T8 treatment that operated with a $\mathrm{pH}$ value of 4.5 (Figure 3 ).

Under the operating conditions of the T12 treatment, a $68 \%$ removal of the initial COD was achieved, which generated an effluent with $297 \mathrm{mg} / \mathrm{L}$ COD. 
$P=0.0000 ; 0.95$ confidence interval

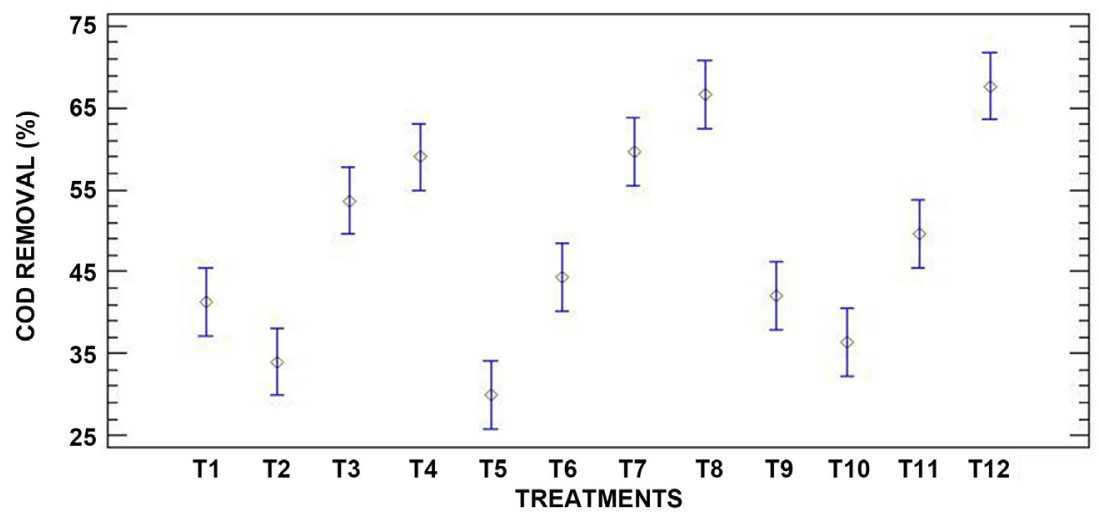

Figure 3. Analysis of variance between treatments.

Authors such as Norma et al. [18], and Ukundimana [19] have reported greater efficiencies in COD removal (75\% - 92\%) when applying anodic oxidation on pretreated leachates. However, both studies used BDD electrodes as cathode and anode, which are more expensive and require a more delicate handling. The use of graphite electrodes in pretreated leachate was reported by Feki et al. [20], but with a low COD removal (22\%), far removed from that achieved in the present study (68\%). Obtaining better removal efficiencies at a greater $j$ can be explained by the increase in the diffusion flow of organic matter from the anode, allowing a more efficient oxidation of organic compounds [21]. Whereas, authors such as Chiang et al. [22], point out that larger $j$ increases the generation of oxidizing chlorine species, which further favor the elimination of pollutants.

Regarding Color removal, Figure 4 shows that during the five hours of reaction under the conditions of the T12 treatment, color was reduced by $90 \%$, obtaining a final effluent with $158 \mathrm{Pt}-\mathrm{Co}$. This decrease can be related to the degradation of humic and fulvic acids that gives color to leachates and are susceptible to oxidation by hydroxyl radicals produced in anodic oxidation [23]. In addition, although maximum color removal was achieved with the higher $\mathrm{pH}$ value, it still remained acidic ( $\mathrm{pH}=6)$, and according to Anglada [12], acidic conditions in the treatment of wastewater by anodic oxidation favors the release of certain oxidants such as $\mathrm{Cl}, \mathrm{Cl}_{2}$ or $\mathrm{HOCl}^{-}$in the anode, which can act directly on the species that give color to the leachate, resulting in better efficiencies in color removal. In general terms, after five hours of electrolysis, and by increasing $j$ from 7 to $22 \mathrm{~mA} / \mathrm{cm}^{2}$, the removal rate increased from $30 \%$ to $68 \%$ in COD and from $76 \%$ to $91 \%$ in Color.

\section{Conclusions}

Anodic Oxidation using graphite electrodes as cathode and anode was effective in removing recalcitrant organic matter present in pretreated leachate, reaching $68 \%$ in COD and $91 \%$ in color, representing a quality in the final effluent of 271 $\mathrm{mg} / \mathrm{L}$ and $151 \mathrm{Pt}-\mathrm{Co}$ in COD and color, respectively, where the best removal conditions were achieved at a $j$ of $22 \mathrm{~mA} / \mathrm{cm}^{2}$ and $\mathrm{pH}$ of 6 . 


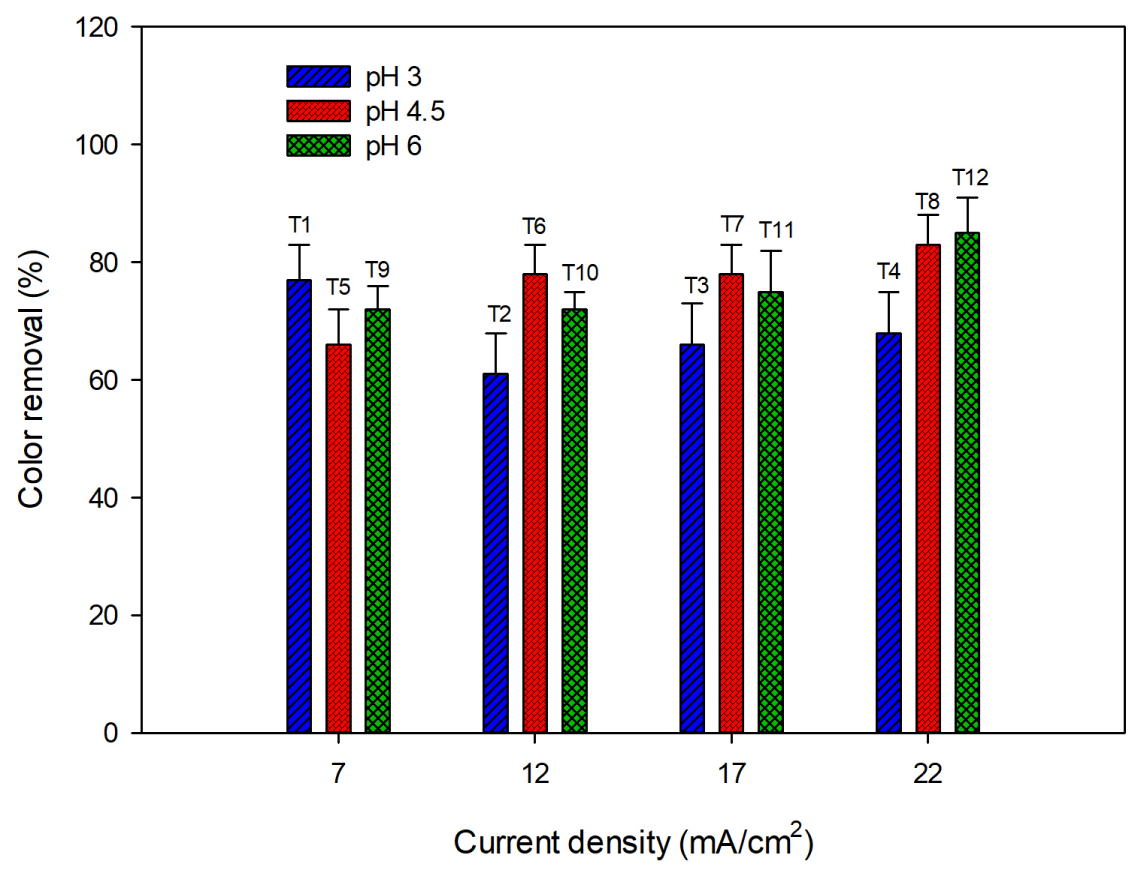

Figure 4. Color removal efficiencies at 5 hours of reaction.

According to the results obtained, anodic oxidation can be a viable and economical alternative with the use of graphite electrodes, as a stage of purification in the final treatment of pretreated leachates.

\section{Conflicts of Interest}

The authors declare no conflicts of interest regarding the publication of this paper.

\section{References}

[1] Bolyard, S.C. and Reinhart, D.R. (2016) Application of Landfill Treatment Approaches for Stabilization of Municipal Solid Waste. Waste Management, 55, 22-30. https://doi.org/10.1016/j.wasman.2016.01.024

[2] Renou, S., Givaudan, J.G., Poulain, S., Dirassouyan, F. and Moulin, P. (2008) Landfill Leachate Treatment: Review and Opportunity. Journal of Hazardous Materials, 150, 468-493. https://doi.org/10.1016/j.jhazmat.2007.09.077

[3] Torres, P., Barba, L.E., Ojeda, C., Martínez, J. and Castaño, Y. (2014) Influence of Leachates Age on Its Physico-Chemical Composition and Toxicity Potential. La Revista U.D.C.A Actualidad \& Divulgación Científica, 17, 245-255. https://doi.org/10.31910/rudca.v17.n1.2014.960

[4] Luna, Y., Otal, E., Vilches, L., Vale, J., Querol, X. and Fernández, C. (2007) Use of Zeolitised Cal Fly Ash for Landfill Leachate Treatment: A Pilot Plant Study. Waste Management, 27, 1877-1883. https://doi.org/10.1016/j.wasman.2006.10.016

[5] Costa, A.M., Alfaia, R.G.D.S.M. and Campos, J.C. (2019) Landfill Leachate Treatment in Brazil: An Overview. Journal of Environmental Management, 232, 110-116. https://doi.org/10.1016/j.jenvman.2018.11.006

[6] Cabeza, A., Urtiaga, A., Rivero, M.J. and Ortiz, I. (2007) Ammonium Removal from 
Landfill Leachate by Anodic Oxidation. Journal of Hazardous Materials, 144, 715-719. https://doi.org/10.1016/j.jhazmat.2007.01.106

[7] Bautista-Ramírez, J.A., Gutiérrez-Hernández, R.F., Nájera-Aguilar, H.A., Martínez-Salinas, R.I., Vera-Toledo, P., Araiza-Aguilar, J.A., Méndez-Novelo, R. and Rojas-Valencia, M.N. (2018) Biorreactor empacado con materiales estabilizados (BEME), como pretratamiento para lixiviados de rellenos sanitarios. Revista MeXicana de Ingeniería Química, 17, 561-571.

https://doi.org/10.24275/uam/izt/dcbi/revmexingquim/2018v17n2/Bautista

[8] Umar, M., Aziz, H.A. and Yusoff, M.S. (2010) Trends in the Use of Fenton, Electro-Fenton and Photo-Fenton for the Treatment of Landfill Leachate. Waste Management, 30, 2113-2121. https://doi.org/10.1016/j.wasman.2010.07.003

[9] Wiszniowski, J., Robert, D., Surmacz-Gorska, J., Miksch, K. and Weber, J.V. (2006) Landfill Leachate Treatment Methods: A Review. Environmental Chemistry Letters, 4, 51-61. https://doi.org/10.1007/s10311-005-0016-Z

[10] Carriazo, J.G., Moreno-Forero, M., Molina, R.A. and Moreno, S. (2010) Incorporation of Titanium and Titanium-Iron Species inside a Smectite-Type Mineral for Photocatalysis. Applied Clay Science, 50, 401-408.

https://doi.org/10.1016/j.clay.2010.09.007

[11] Morais, J.L. and Zamora, P.P. (2005) Use of Advanced Oxidation Processes to Improve the Biodegradability of Mature Landfill Leachates. Journal of Hazardous Materials, 123, 181-186. https://doi.org/10.1016/j.jhazmat.2005.03.041

[12] Anglada, A., Urtiaga, A. and Ortiz, I. (2009) Pilot Scale Performance of the Electro-Oxidation of Landfill Leachate at Boron-Doped Diamond Anodes. Environmental Science \& Technology, 43, 2035-2040. https://doi.org/10.1021/es802748c

[13] Fernandes, A., Spranger, P., Fonseca, A.D., Pacheco, M.J., Ciríaco, L. and López, A. (2014) Effect of Electrochemical Treatment on the Biodegradability of Sanitary Landfill Leachates. Applied Catalysis B: Environmental, 144, 514-520. https://doi.org/10.1016/j.apcatb.2013.07.054

[14] APHA (2012) Standard Methods for the Examination of Water and Wastewater, 22nd Edition. American Public Health Association/American Water Works Association/Water Environment Federation, Washington DC.

[15] Foo, K.Y. and Hameed, B.H. (2009) An Overview of Landfill Leachate Treatment via Activated Carbon Adsorption Process. Journal of Hazardous Materials, 171, 54-60. https://doi.org/10.1016/j.jhazmat.2009.06.038

[16] Turro, E., Giannis, A., Cossu, R., Gidarakos, E., Mantzavinos, D. and Katsaounis, A. (2012) Reprint of: Electrochemical Oxidation of Stabilized Landfill Leachate on DSA Electrodes. Journal of Hazardous Materials, 207, 73-78.

https://doi.org/10.1016/j.jhazmat.2012.01.083

[17] Papastavrou, C., Mantzavinos, D. and Diamadopoulos, E. (2009) A Comparative Treatment of Stabilized Landfill Leachate: Coagulation and Activated Carbon Adsorption vs. Electrochemical Oxidation. Environmental Technology, 30, 1547-1553. https://doi.org/10.1080/09593330903252240

[18] Norma, D., Fernandes, A., Pacheco, M.J., Ciríaco, L. and Lopes, A. (2012) Electrocoagulation and Anodic Oxidation Integrated Process to Treat Leachate from a Portuguese Sanitary Landfill. Portugaliae Electrochimica Acta, 30, 221-234. https://doi.org/10.4152/pea.201203221

[19] Ukundimana, Z., Omwene, P.I., Gengec, E.R.H.A.N., Can, O.T. and Kobya, M. (2018) Electrooxidation as Post Treatment of Ultrafiltration Effluent in a Landfill Leachate MBR Treatment Plant: Effects of BDD, Pt and DSA Anode Types. Elec- 
trochimica Acta, 286, 252-263. https://doi.org/10.1016/j.electacta.2018.08.019

[20] Feki, F., Aloui, F., Feki, M. and Sayadi, S. (2009) Electrochemical Oxidation Post-Treatment of Landfill Leachates Treated with Membrane Bioreactor. Chemosphere, 75, 256-260. https://doi.org/10.1016/j.chemosphere.2008.12.013

[21] Yousssef, S., Lamia, A. and Ridha, A. (2010) Electrochemical Degradation of Chlorpyrifos Pesticide in Aqueous Solutions by Anodic Axidation at Boron-Doped Diamond Electrodes. Chemical Engineering Journal, 161, 167-172. https://doi.org/10.1016/j.cej.2010.04.060

[22] Chiang, L.C., Chang, J.E. and Wen, T.C. (1995) Indirect Oxidation Effect in Electrochemical Oxidation Treatment of Landfill Leachate. Water Research, 29, 671-678. https://doi.org/10.1016/0043-1354(94)00146-X

[23] Méndez, R.I., Castillo, E.R., Sauri, M.R., Quintal, C.A., Giácoman, G. and Jímenez, B. (2009) Comparación de cuatro tratamientos fisicoquímicos de lixiviados. Revista internacional de contaminación ambiental, 25, 133-145. 